\title{
The Effect of Ploidy on Growth and Feeding Pattern of Diploid and Triploid Turbot Scophthalmus maximus Under Communal Rearing Condition
}

\author{
Ilhan Aydin ${ }^{1, *}$ (1) \\ ${ }^{1}$ General Directorate of Agricultural Research and Policies, Ankara, Turkey
}

How to cite

Aydın, I. (2021). The Effect of Ploidy on Growth and Feeding Pattern of Diploid and Triploid Turbot Scophthalmus maximus Under Communal Rearing Condition. Turkish Journal of Fisheries and Aquatic Sciences, 21, 275-281. http://doi.org/10.4194/1303-2712-v21_6_02

\section{Article History}

Received 12 December 2020

Accepted 14 March 2021

First Online 18 March 2021

\section{Corresponding Author}

Tel.: +903123076036

E-mail: ilhan61@gmail.com

\author{
Keywords \\ Turbot \\ Ploidy \\ Growth performance \\ Competitivity \\ Behaviour
}

\begin{abstract}
Triploidy induction is a useful tool to produce sterile fish that prevents interbreeding of farmed fish with wild counterparts. In this study, growth performance and feed conversion rates of 12 -months old diploid and triploid turbot that reared both communally and separately for 16 months at constant water temperature determined. At the end of the experiment, diploid, triploid, and communally reared groups reached an average weight of $672.4 \pm 21.0 \mathrm{~g}, 659.2 \pm 25.3 \mathrm{~g}$ and $660.5 \pm 12.0 \mathrm{~g}$, respectively. Any significant differences were not observed in the weight of separately reared diploid and triploid turbot groups. In contrast, triploid fish in the communal group were significantly heavier than diploids at the end of the rearing period. The feed conversion rate of the ploidy group did not show any significant difference between groups. The highest mean specific growth rate was observed in the triploids in communal groups, whereas the diploids in communal groups had the lowest mean specific growth rate. The weight and length gain rates of the groups were similar. Diploid turbot growth appeared to be negatively affected by communal ploidy rearing. The results of the present study indicate that triploid turbot farm escapees may be advantageous in terms of growth in nature.
\end{abstract}

\section{Introduction}

Turbot Scophthalmus maximus, also known as, Psetta maxima, is a marine demersal sinistral form of flatfish. From the Black Sea to the Baltic Sea, it exists in a wide geographic range. Turbot subjects to intensive fishing pressure because of its high commercial value (Nikolov et al., 2015, Prado et al., 2018a; Firidin et al., 2020). According to a recent report, turbot's catches drastically decreased from 11548 tonnes in 1994 to 5843 tonnes in 2018 (FAO, 2020a). Such reduction due to overfishing, the result of eutrophication and changes in the coastal ecosystem. Aquaculture practices and stock enhancement programs are vital to meet the high market demand, (Aydin et al., 2020). Artificial spawning and seed production techniques are widely applied in Europe (Ruyet, 2002; Lugert et al., 2019), Turkey (Aydin et al., 2020; Polat et al., 2021), China (Cang et al., 2018), and Korea (Han et al., 2018). Moreover, turbot aquaculture farms have mainly been established in Europe and China during the last decades reaching a total production of 59615 tonnes (FAO, 2020b). On the other hand, countries such as Turkey (Zengin et al., 2007), Russia (Maslova, 2002), Denmark (Støttrup, 2002), Belgium (Delbare and Clerck, 2000), Spain and Norway (Coughlan et al., 1998) have released turbot juveniles to enhance depleted turbot stock as well as take precautionary measures to encourage the amount of spawning stock biomass. Despite the benefit of providing an alternative source of protein, there is public concern regarding hatchery-reared fish moving to the wild environment (either escapee from the farm or intentional releases for stock enhancement) for the sustainability of natural resources (Prado et al., 2018b). 
Although triploidy induction is a common method used in plants, early trials of triploidy induction for fish date back to only the 1940s (Gjedrem, 2005). In general, when the fish reach sexual maturity, a low growth rate, deterioration in meat quality, and mortality are observed. However, sexual maturity is not expected in triploid fish, so superior growth, high meat quality and low mortality are expected. (Thorgaard, 1986; Dunham, 1990; Hussain et al., 1995). To prevent these undesirable traits and to improve yield, triploid induction extensively utilizes in freshwater and anadromous fishes, marine fishes, and shellfish (Piferrer et al., 2009), as well as turbot. Moreover, to benefit from different fields, transgenesis has recently been applied to several fish species, such as Atlantic salmon, taking place in markets around the USA (Cebeci et al., 2020). However, transgenic fish still poses questions about the potentially deleterious impact of escaping or released transgenic fish on natural habitats. Therefore, sterile triploid fish also recommend eliminating the risk of transgenesis fish escaped from farm to natural habitat (Piferrer et al., 2009). On the other hand, the impact of triploidy is species-specific and different results have reported in many fish species (Arai, 2001; Felip, 2001).

The performance of triploid fish in their natural environment has mainly documented in terms of reproductive interactions between released/escapees triploid and diploid wild relatives in different fish species (Piferrer et al., 2009). On the other hand, the growth and feeding behaviour of triploid fish reared in communal condition is rare (Mori et al., 2006). Aquaculture performance of triploid barfin flounder was studied under the communal rearing conditions and Benfey (1999) explained that behavioural interactions between triploids and diploid controls are confounding.

Triploid induction in turbot can be obtained by cold shock application just after fertilization (Piferrer et al., 2000; 2003). There are many reports on triploid turbot biology such as early cleavage patterns of eggs (Aydin and Okumuş 2017), growth and gonadal development (Cal et al., 2006), sex-dependent synaptic behaviour (Cuñado et al., 2002), flesh quality (Hernández-Urcera et al., 2016; Ayala, et al., 2020), digestive enzyme activity (Domingues et al., 2019), haematology (Cal et al., 2005), immunology (Budiño et al., 2006), and body morphology (Hernández-Urcera et al., 2012). In literature, several studies have indicated that triploid turbot exhibits similar growth and feeding responses compared to their diploid counterparts (Piferrer et al., 2003; Cal et al. 2006; Domingues et al., 2019). The comparison of growth and feed utilization of triploid and diploid fish reared in communal is noteworthy to assess the behavioural effect of diploid or triploid fish on their counterparts and to figure out the possible effect of either released or escapees cultured triploid turbot on the wild environment. However, there have been no investigations on the effects of growth and feed utilization of triploid turbot under the circumstantiate of communal rearing with its diploid partners. Therefore, this study aimed to determine the growth and feed usage of the triploid and diploid turbots on the circumstantiality of mutual rearing. For this purpose, individually tagged diploid and triploid turbots, reared both separately and in the same place for 15 months, were studied.

\section{Materials and Methods}

\section{Fish material and Triploidy Application}

Turbot broodstock used in the experiment were obtained from Marine Fish Hatchery in Central Fisheries Research Institute, Trabzon, Turkey. Eggs were fertilized in seawater by mixing with stripped milt from two different males for one female. After $20 \mathrm{~min}$ of fertilization for triploidy, fertilized eggs were exposed to cold water just below $0^{\circ} \mathrm{C}$ for $6.5 \mathrm{~min}$ as recommended by Piferrer et al. (2000) and Aydin and Okumuş (2017). Fertilized eggs were incubated at $\sim 14^{\circ} \mathrm{C}$ for 5 days and larval rearing was carried out according to Çiftçi et al. (2002). Eggs, larva, and juveniles from each ploidy were kept separately during all rearing period.

\section{Ploidy Assessment}

When the experimental fish reached 6 months old, 120 control (diploid) and blood samples from 240 cold shock treated (triploid) juveniles were taken for ploidy evaluation. Ploidy levels were determined by measuring the long axis of erythrocytes (40 erythrocytes per fish) from dried smears of their blood under a light microscope (Piferrer et al., 2000). The long axis of erythrocytes was $11.4 \pm 0.02 \mu \mathrm{m}$ in diploids, and $14.2 \pm 0.16 \mu \mathrm{m}(\mathrm{P}<0.001)$ in triploids, and the triploid rate was calculated as $99.2 \%$.

\section{Rearing Conditions and Experimental Design}

Turbots were reared in a flow-through system at the Marine Hatchery in Central Fisheries Research Institute in Trabzon, Turkey. Seawater with a $17.9 \pm 0.03$ $\%$ salinity was pumped from a depth of $40 \mathrm{~m}$, and the water exchange rate was 20 times a day for all experimental tanks. The seawater used in the hatchery was pre-treated with pressurized sand filters and a UV sterilization system. Pre-treated seawater was then pumped to all tanks from one reservoir with heating systems to maintain the desired temperature at all times. The water was aerated with two air stones at a moderate rate in each tank. Temperatures were measured twice a day; dissolved oxygen (DO), $\mathrm{pH}$ and salinity values were measured once a week. During the entire grow-out period, the water temperature was kept at $18.0 \pm 1.14^{\circ} \mathrm{C}$, pH was $6.98-8.08$, the salinity was 17.8 18.2 and DO was higher than $80 \%$.

Three replicates were formed in a total of three groups: only diploid (150 fish), only triploid (150 fish), and diploid (75 fish) and triploid (75 fish) turbot grown 
communally. For the first period of the experiment $(5$ months), 12 months post-hatching turbot were stocked into nine indoor, round-cornered square water tanks $(500 \mathrm{~L})$. For the rest of the experimental period (10 months), nine indoor raceway tanks $(2000 \mathrm{~L})$, each stocked with 50 fish, were used. All fish were individually marked with PIT tags (TX1400L, Biomark) and weighed individually.

\section{Feed Consumption and Growth}

Turbot diet containing $52 \%$ crude protein, $10 \%$ crude lipid, $1 \%$ crude fibre and $13 \%$ crude ash having gross energy of $19.8 \mathrm{~kJ} / \mathrm{g}$ (Kiliç Yem Corporation, Turkey) was used in the experiments. Experimental fish were fed by hand with extruded turbot diet once a day to apparent satiation (ad libitum) (Aydin et. al., 2011). The feed weight consumed by the fish in each tank was measured. Uneaten pellets were collected by siphoning $45 \mathrm{~min}$ after each feeding to be included in calculations to identify the real feed intake and FCR. The fish were starved for $24 \mathrm{~h}$ before each measurement. Initial stocking density was determined as $10 \mathrm{kgm}^{2}$ and did not exceed common standards. Growth parameters were recorded monthly. Growth parameter indices; specific growth rate (SGR), length and weight gain ratio (LGR and WGR), feed conversion rate (FCR), were calculated according to Altinok et al. (2020) based on the following formulae;

SGR=100x (In (final weigth)-In(initial weigth))/day

LGR (\%)=100x(final length-initial length)/initial length

WGR (\%)=100x (final weigth - initial weigth)/initial weigth

$F C R=$ feed intake/weigth gain

\section{Statistical Analysis}

Data were analyzed by one-way analysis of variance (ANOVA), and if significant differences were found, means were compared by the Tukey's test $(P<0.05)$ after confirmation of normality and homogeneity of variance (Zar, 1999). Statistical analyses were performed with Statistica 7 (Stat Soft. Inc. Tulsa, OK, USA).

\section{Results}

The initial, periodic, and final average weight of each fish group are presented in Figure 1. As presented in Figure 1, the initial mean weights of the fish groups were found to be similar ( $P>0.05)$. Diploid, triploid, and communal reared turbot groups were grown at the proper constant water temperature (at $18^{\circ} \mathrm{C}$ ) for 16 months and had an average weight of $672.4 \pm 21.0 \mathrm{~g}$, $659.2 \pm 25.3 \mathrm{~g}$ and $660.5 \pm 12,0 \mathrm{~g}$, respectively (Figure 1). When both ploidies reared together, the weight of diploid turbot was found be $604 \pm 28.5 \mathrm{~g}$, whereas their counterpart triploid turbot was $716 \pm 39,3 \mathrm{~g}$. Turbot weight at the end of the experimental period was not significantly affected by ploidy when reared separately, but when reared communally, they were significantly affected by ploidy $(\mathrm{P}<0.05)$ (Figure 1 ).

Growth parameter indices of FCR, SGR, WGR, and LGR are presented in Table 1 . The feed conversion rate (FCR) of the diploid groups was slightly higher than that of the other groups; however, no statistically significant difference was found. The growth parameters SGR, WGR, and LGR were statistically different between the experimental groups $(P<0.05)$ (Table 1$)$. The highest mean SGR was found in the triploid communal groups $(0.51 \pm 0.01)$, while the lowest SGR was observed in

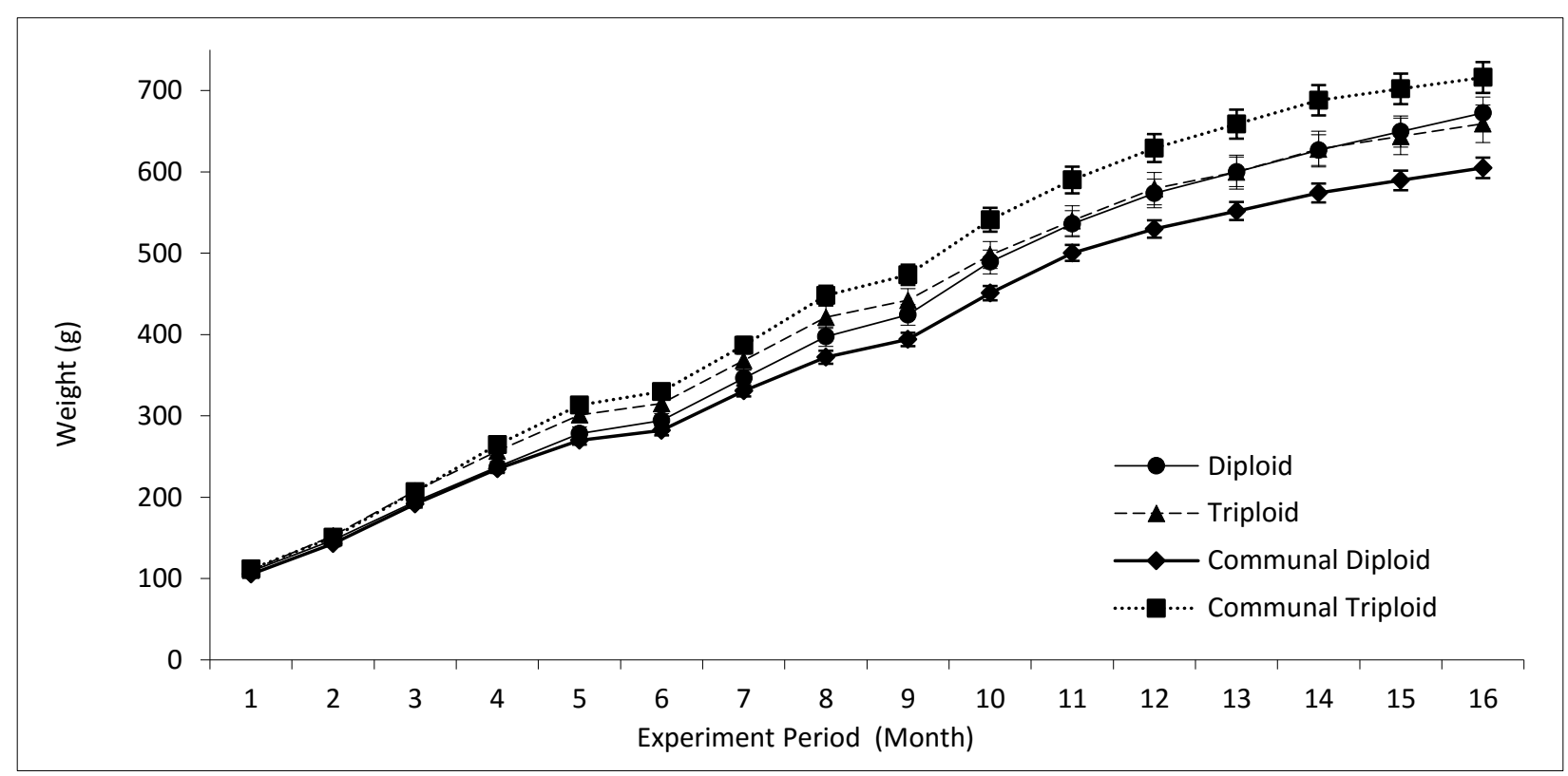

Figure 1. The weight increase of turbot S. maximus during 15 months rearing period at $18^{\circ} \mathrm{C}$. Diploid $(\bullet)$, triploid $(\boldsymbol{\Delta})$, communal diploid $(\bullet$ ) and communal triploid ( $\square$ ). 
diploid communal groups $(0.48 \pm 0.01)$. However, similar SGR values were found in diploid, triploid and, communal groups $(0.50 \pm 0.01)(P<0.05)$. Similar to SGR values, diploid (533.58 \pm 12.85$)$, triploid (513.88 \pm 12.15$)$, and communal groups $(522.53 \pm 12.83)$ had statistical similar WGR values. In the meantime, WGR was the highest $(558.07 \pm 19.02)$ in triploid communal groups while diploid communal groups had the lowest WGR (486.97 \pm 16.30$)$. Similarly, communal diploid fish displayed relatively the lowest LGR (79.91) while communal triploid fish had the highest LGR (86.44). LGR of the other groups were found to be similar $(P<0.05)$ (Table 1.).

\section{Discussion}

Triploid induction has a different effect on fish growth and feeding behaviours. It depends on various factors such as fish size, fish species, and rearing conditions (either separately or communal). Superior effect of triploid fish was observed during sexual maturity due to sterility, along with the period of puberty, triploidy did not lead to any weight increase. Studies indicated that triploids grew similarly to diploids in many teleost species (Fernandez-Pato et al. 1996; Cal et al. 2006, Maxime 2008; Piferrer et al., 2009). Arai (2001) reported that under independent rearing conditions, the growth of triploid rainbow trout, Oncorhynchus mykiss and ayu, Plecoglossus altivelis are nearly the same as that of diploids. Turbot also exhibits similar growth for both ploidy during juvenile and growing phase (Piferrer et al., 2003; Cal et al. 2006; Domingues et al., 2019). In the present study, at the end of 15 of months rearing the mean weight of turbot, S. maximus reached $600-700 \mathrm{~g}$ from $100 \mathrm{~g}$. Based on the growth and feeding patterns, it has pointed out that, performance of separately reared diploid and triploid turbot are similar. Like previous studies, this study demonstrated that before the onset of sexual maturation, ploidy did not significantly affect the growth of diploid and triploid turbot, which were reared at separate tanks but in similar environment.

The growth and feeding behaviour of triploid fish reared under the communal condition with their diploid is uncertain, and in literature, there is no information on the triploid turbot. Only several published studies have shown that the ploidy did not affect the growth of barfin flounder, Verasper moseri (Mori et al., 2006) and loaches, Misgurnus anguillicaudatus (Horei et al., 2004) in the communal rearing environment. On the other hand, in another study, it has been shown that triploid Atlantic salmon, Salmo salar grew better than their diploid partners when they were reared together (Galbreath et al., 1994). The main objective of this study was to determine cold-shock induced triploid turbot performances under communal rearing condition with their diploid counterparts. Therefore, in this study, the performance of triploid turbot in communal rearing with diploids was determined.

The effects of ploidy on fish physiology have not been fully elucidated (Cotter et al., 2000) and triploid fish exhibits different behavioural and physiological responses when compared with their diploid counterparts (Piferrer et al. 2009; Hernández-Urcera et al. 2012; Hernández-Urcera et al. 2016). Many studies indicate that the performance of ploidy is speciesspecific, and there are many different results obtained from various fish species (Arai, 2001; Felip 2001; Maxime 2008; Piferrer et al., 2009; Fraser et al., 2012). Moreover, the effect of ploidy on fish varies between individuals of the same species, even though they are reared under similar conditions (Galbreath et al., 1994; McGeachy et al., 1995). Therefore, in contrast with a previous study carried out with other species, the present study demonstrates that the growth and feed utilization of triploid turbot were higher than the diploid counterparts in communal rearing condition. The reason for triploid turbot growth to be superior to their diploid sibling under communal rearing is probably due to getting more feed or being more competitive during feeding.

The benefits of using triploid fish in fisheries management are; to avoid the problems associated with undesirable reproduction and ecological and genetic impacts of cultured fish on the wild stock (Piferrer et al., 2009; Fraser et al., 2012). The use of triploid fish also ensures that any escapees from aquaculture facilities are not able to reproduce in the wild. As an exotic species, sterile triploid fish may be cultured in the targeted region where fish do not exist naturally in that habitat. Thus, triploid fishes such as salmonids, ayu (Plecoglossus altivelis), loach (Misgurnus anguillicaudatus), and grass carp (Ctenopharyngodon idella) are used in releasing (Powell et al., 2009;

Table 1. Growth parameter indices of each group. Superscripts $(a, b$ and $c)$ indicate significant differences $(P<0.05)$.

\begin{tabular}{lcccc}
\hline Group & FCR & SGR & WGR & LGR \\
\hline Diploid & $1.22 \pm 0.03^{\mathrm{a}}$ & $0.50 \pm 0.01^{\mathrm{b}}$ & $533.58 \pm 12.85^{\mathrm{b}}$ & $83.27 \pm 1.12^{\mathrm{b}}$ \\
Triploid & $1.21 \pm 0.01^{\mathrm{a}}$ & $0.50 \pm 0.01^{\mathrm{b}}$ & $513.88 \pm 12.15^{\mathrm{b}}$ & $82.97 \pm 1.16^{\mathrm{b}}$ \\
Communal & $1.21 \pm 0.02^{\mathrm{a}}$ & $0.50 \pm 0.01^{\mathrm{b}}$ & $522.53 \pm 12.83^{\mathrm{b}}$ & $83.18 \pm 1.20^{\mathrm{b}}$ \\
Diploid Communal & - & $0.48 \pm 0.01^{\mathrm{a}}$ & $486.97 \pm 16.30^{\mathrm{a}}$ & $79.91 \pm 1.58^{\mathrm{a}}$ \\
Triploid Communal & - & $0.51 \pm 0.01^{\mathrm{c}}$ & $558.07 \pm 19.02^{\mathrm{c}}$ & $86.44 \pm 1.77^{\mathrm{c}}$ \\
\hline
\end{tabular}

FCR-Feed conversion rate, SGR-Weight-Specific growth rate, WGR-Weight gain ratio, LGR-Length gain ratio. 
Beaumont et al., 2010). Also, one more common use of triploidy is sport fishery. Similarly, the release of triploid turbot may be useful because of a low level of genetic diversity of the turbot populations (Han, Lee, Jung, Aydin, \& Lee, 2018; Prado et al., 2018; Firidin et al., 2020). However, there are still tremendous information gaps in the performance of triploid fish, particularly when they have been released or escaped into wild environments (Fraser et al., 2012). More research is still needed on this topic to understand triploid fish performance either in communal or wild environments.

\section{Conclusion}

The impact of escapees from aquaculture is of general concern for the sustainability of the natural resource. Triploidy is under consideration to avoid this concern because of its sterility. Despite this advantage, there is a debate on the effect of release or escapee triploid fish in a wild environment. In this study, the performance of triploid turbot in communal rearing with diploids was determined. Before the onset of sexual maturation, Ploidy did not have a major effect on diploid and triploid turbot growth, which were grown in different tanks but under similar conditions. On the other hand, under communal rearing conditions, the growth and feed utilization of triploid turbot were found to be higher than the diploid counterparts. The reason for triploid turbot growth to be superior to their diploid sibling under communal rearing is probably due to getting more feed or being more competitive during feeding. Nevertheless, further research on this subject is required to understand the performance of triploid fish under communal condition and in a wild environment. Finally, it should be highlighted that triploid turbot may impact the wild population when they release to the same environment in terms of feeding and growth. Thus, to use of triploid fish in releasing programme should be under consideration.

\section{Ethical Statements}

All triploidy process and experimental protocols have been approved by Veterinary Control and Research Institute, Animal Experiments Local Ethics Committee (No;22-003/2) under the General Directorate of Agricultural Research and Policy surveillance.

\section{Funding information}

This study was funded by the Scientific and Technological Research Council of Turkey (TÜBITAK) (Grand number 108R014).

\section{Author Contributions}

IA: Conceptualization, funding acquisition, project administration, methodology, formal analysis, investigation, writing-review \& editing.

\section{Conflict of interest}

The author declares that there are no conflicts of interest regarding the publication of this article

\section{Acknowledgment}

The author thanks to the personnel of the Aquaculture unit of the Central Fisheries Research Institute (SUMAE) for their contribution and technical assistance during the experiments.

\section{References}

Altinok, I., Ozturk, R.C., Capkin, E., \& Kalayci, G. (2020). Experimental crossbreeding reveals variation in growth among brown trout (Salmo trutta) strains and their reciprocal crossbreeds. Aquaculture, 521:734983. https://doi.org/10.1016/j.aquaculture.2020.734983

Aydin, I., Polat, H., \& Sahin, T. (2020). Reproductive performance of wild and hatchery-reared black sea turbot, Psetta maxima, in the southern black sea coast. Turkish Journal of Fisheries and Aquatic Sciences, 20(5), 351-357. https://doi.org/10.4194/1303-2712-v20_5_03

Aydın, i., \& Okumuş, i. (2017). Effects of triploid induction to the early cleavage patterns of black sea turbot (Psetta maxima) embryos. Genetics of Aquatic Organisms, 1(1), 15-20. https://doi.org/10.4194/2459-1831-v1_1_03

Arai, K., (2001). Genetic improvement of aquaculture finfish species by chromosome manipulation techniques in Japan. Aquaculture, 197, 205-228 https://doi.org/10.1016/S0044-8486(01)00588-9

Ayala, M.D., Hernández-Urcera, J., Santaella, M., Graciá, M.C.M., López-Albors, O., \& Cal, R. (2020). Influence of the myotome zone and sex on the muscle cellularity and fillet texture of diploid and triploid turbots Scophthalmus maximus L. In Veterinary Research Forum (Vol. 11, No. 2, p. 105). Faculty of Veterinary Medicine, Urmia University, Urmia, Iran.

Benfey, T.J., The physiology and behaviour of triploid fishes. Review of Fish Science. 7, 39-67, (1999). https://doi.org/10.1080/10641269991319162

Budiño, B., Cal, R.M., Carla-Piazzon, M. \& Lamas, J. (2006) The activity of several components of the innate immune system in diploid and triploid turbot. Comp. Biochem.Physiol. A, 145, 108-113. https://doi.org/10.1016/j.cbpa.2006.05.007

Cal, R.M., Vidal, S., Camacho, T., Piferrer, F., \& Guitian, F.J. (2005). Effect of triploidy on turbot haematology. Comparative Biochemistry and Physiology Part A: Molecular \& Integrative Physiology, 141(1), 35-41. https://doi.org/10.1016/j.cbpb.2005.03.007

Cal, R.M., Vidal, S., Gómez, C., Álvarez-Blázquez, B., Martínez, P., \& Piferrer, F. (2006). Growth and gonadal development in diploid and triploid turbot (Scophthalmus maximus). Aquaculture, 251(1), 99-108. https://doi.org/10.1016/j.aquaculture.2005.05.010

Cang, P., Yang, Z., \& Duan, Y. (2018). The Economies of Scale of Turbot Industrial Running Water Aquaculture System in China: A Case from Shandong Province. Turkish Journal of Fisheries and Aquatic Sciences, 18, 167-173. http://doi.org/10.4194/1303-2712-v18_1_19

Cebeci, A., Aydın, İ., \& Goddard, A. (2020). Bigger, stronger, better: Fish transgenesis applications and methods. 
Biotech Studies, 29, 85-97.

http://doi.org/10.38042/biost.2020.29.02.05

Coughlan, J.P., Imsland, A.K., Galvin, P.T., Fitzgerald, R.D., Naevdal, G., \& Cross, T.F. (1998). Microsatellite DNA variation in wild populations and farmed strains of turbot from Ireland and Norway. Journal of Fish Biology, $52,916-922$. https://doi.org/10.1111/j.1095-8649.1998. tb00592.x

Cotter, D., O'Donovan, V., O'Maoiléidigh, N., Rogan, G., Roche, N., \& Wilkins, N.P. (2000). An evaluation of the use of triploid Atlantic salmon (Salmo salar L.) in minimising the impact of escaped farmed salmon on wild populations. Aquaculture, 186(1-2), 61-75. https://doi.org/10.1016/S0044-8486(99)00367-1

Cuñado, N., Terrones, J., Sánchez, L., Martínez, P., \& Santos, J.L. (2002). Sex-dependent synaptic behaviour in triploid turbot, Scophthalmus maximus (Pisces, Scophthalmidae). Heredity, 89(6), 460-464. https://doi.org/10.1038/sj.hdy.6800165

Çiftci, Y., Üstündağ, C., Erteken, A., Özongun, M., Ceylan, B., Haşimoğlu, A., ... \& Hara, S. (2002). Manual for the seed production of turbot, Psetta maxima in the Black Sea. Special Publication, 2, 1-80.

Delbare, D., \& De Clerck, R. (2000, September). Release of reared turbot in Belgian coastal waters as a tool for stock enhancement. In 2000 ICES Annual Science Conference (pp. 27-30)

Domingues, P., Hernández-Urcera, J., Cal, R., Olivares, A., Chimal, M., Sánchez, A., ... \& Gallardo, P. (2019). Effect of triploidy on digestive enzyme activity of early stages of turbot (Scophthalmus maximus). Fish Physiology and Biochemistry, 45(2), 573-582. https://doi.org/10.1007/s10695-019-00610-z

Dunham, R.A., (1990). Production and Use of Monosex or Sterile Fishes in Aquaculture. Rev. Aquat. Sci., 2, 1-17.

FAO. (2020a). Cultured Aquatic Species Information Programme (Psetta maxima). Retrieved from http://www.fao.org/fishery/culturedspecies/Psetta_ma xima/en\#tcNA008C

FAO. (2020b). http://www.fao.org/fishery/statistics/globalcapture-production/query/en

Fraser, T.W.K., Per Gunnar Fjelldal, Tom Hansen \& Ian Mayer (2012): Welfare Considerations of Triploid Fish, Reviews in Fisheries Science, 20:4, 192-211. https://doi.org/10.1080/10641262.2012.704598

Felip, A., Piferrer, F., Zanuy, S., \& Carrillo, M. (2001). Comparative growth performance of diploid and triploid European sea bass over the first four spawning seasons. Journal of Fish Biology, 58(1), 76-88. https://doi.org/10.1111/j.1095-8649.2001.tb00500.x

Fernandez-Pato, C.A., Martinez-Tapia, I., \& Vazquez, E. (1996) Comparative performance of growth in diploid and triploid turbot (Scophthalmus maximus L.). ICES, 96:1-6

Firidin, S., Ozturk, R.C., Alemdag, M., Eroglu, O., Terzi, Y., Kutlu, I., ... \& Aydin, I. (2020). Population Genetic Structure of Turbot (Scophthalmus maximus L., 1758) in the Black Sea. Journal of Fish Biology, 97(4), 1154-1164. https://doi.org/10.1111/jfb.14487

Galbreath, P.F., Jean, W.S., Anderson, V., \& Thorgaard, G.H. (1994). Freshwater performance of all-female diploid and triploid Atlantic salmon. Aquaculture, 128(1-2), 4149. https://doi.org/10.1016/0044-8486(94)90100-7

Gjedrem, T. (2005). Selection and Breeding Programs in Aquaculture, Springer, Hollanda, $364 \mathrm{~s}$. https://doi.org/10.1007/1-4020-3342-7
Han, J., Lee, W., Jung, T.S., Aydin, L., \& Lee, W.J. (2018) Evaluation of genetic diversity and population genetic parameters of farmed turbot species (Scophtalmus maximus) from france, Turkey, and Korea. Genetics of Aquatic Organisms, 2, 1-6.

https://doi.org/10.4194/2459-1831-v2_1_01

Hernández-Urcera J., Torres E., Barreiro D., Barreiro-Lois A., Alonso J., Cal R. \& Rotllant J. (2012) Induction of triploidy in turbot (Scophthalmus maximus) does not affect gross body morphology and skeleton characteristics. Aquaculture, 338, 309-312.

https://doi.org/10.1016/j.aquaculture.2012.01.023

Hernández-Urcera, J., Ayala, M.D., Santaella, M., Periago, M.J., López-Albors, O., \& Cal, R., (2016). Effect of triploidy on muscle cellularity and flesh quality of turbot (Scophthalmus maximus). Aquac. Res., 48, 3606-3617. https://doi.org/10.1111/are. 13186.

Hussain, M.G., Rao, G.S.P., \& Humayun, N.M., (1995). Comparative Performance of Growth, Biochemical Composition and Endocrine Profiles in Diploid and Triploid Tilapia Oreochromis niloticus L.. Aquaculture, 138, 87-97. https://doi.org/10.1016/0044-8486(95)01079-3

Horei, S., Taniura, K., Umino, T., Nakagawa, H \& Arai, K., (2004) Performance of the Progeny of Natural Tetraploid Loaches in Long-Term Communal Rearing Experiments under a Laboratory Condition. Suisanzoshoku, 52(1) 9198.

Lugert, V., Hopkins, K., Schulz, C., Schlicht, K., \& Krieter, J. (2019). The Course of Growth, Feed Intake and Feed Efficiency of Different Turbot (Scophthalmus maximus) Strains in Recirculating Aquaculture Systems. Turkish Journal of Fisheries and Aquatic Sciences, 19, 305-312. http://doi.org/10.4194/1303-2712-v19_4_05

Maxime, V., (2008). The Physiology of Triploid Fish: Current Knowledge and Comparisons with Diploid Fish, Fish and Fisheries, 9, 67-78. https://doi.org/10.1111/j.1467-2979.2007.00269.x

Maslova, O.N. (2002). Problems and Achievements in Seed Production of the Black Sea Turbot in Russia. Turkish Journal of Fisheries and Aquatic Sciences, 2, 23-27.

McGeachy, S.A., Benfey, T.J. \& Friars, G.W. (1995) Fresh- water performance of triploid Atlantic salmon (Salmo salar) in New Brunswick aquaculture. Aquaculture, 137, 333-341. https://doi.org/10.1016/0044-8486(95)01100-5

Mori, T., Saito, S., Kishioka, C., \& Arai, K., (2006). Aquaculture Performance of Triploid Barfin Flounder Verasper moseri. Fisheries Sciences, 72, 270-277. https://doi.org/10.1111/j.1444-2906.2006.01148.x

Nikolov, V., Ivanova, P., Dzhembekova, N., Panayotova, M., Raykov, V., \& Dobrovolov, I. (2015). Application of allozyme markers for screening of turbot populations along Western Black Sea coast. zoonoses, 79, 1-15.

Piferrer, F., Cal, R.M., Álvarez-Blázquez, B., Sánchez, L., \& Martinez, P. (2000). Induction of triploidy in the turbot (Scophthalmus maximus): I. Ploidy determination and the effects of cold shocks. Aquaculture, 188(1-2), 79-90. https://doi.org/10.1016/S0044-8486(00)00306-9

Piferrer, F., Cal, R.M., Gómez, C., Bouza, C., \& Martínez, P. (2003). Induction of triploidy in the turbot (Scophthalmus maximus): II. Effects of cold shock timing and induction of triploidy in a large volume of eggs. Aquaculture, 220(1-4), 821-831. https://doi.org/10.1016/S0044-8486(02)00535-5

Piferrer F, Beaumont A, Falguiere J-C, Flajshans M, Haffray P, 
\& Colombo L (2009) Polyploid fish and shellfish: production, biology and applications to aquaculture for performance improvement and genetic containment. Aquaculture, 293(3-4): 125-156. https://doi.org/10.1016/j.aquaculture.2009.04.036

Polat, H., Ozturk, R.C., Terzi, Y., Aydin, I., Kucuk, E. (2021). Effect of Photoperiod Manipulation on Spawning Time and Performance of Turbot (Scophthalmus maximus). Aquaculture Studies, 21, 109-115. http://doi.org/10.4194/2618-6381-v21_3_03

Prado, F.D., Vera, M., Hermida, M., Bouza, C., Pardo, B.G., Vilas, R., ... \& Martínez, P. (2018a). Parallel evolution and adaptation to environmental factors in a marine flatfish: Implications for fisheries and aquaculture management of the turbot (Scophthalmus maximus). Evol Appl., 2018; 00:1-20. https://doi.org/10.1111/eva.12628

Prado, F.D., Vera, M., Hermida, M., Blanco, A., Bouza, C., Maes, G.E., Volckaert, F.A.M., ... \& Martínez, P. (2018b). Tracing the genetic impact of farmed turbot Scophthalmus maximus on wild populations. Aquaculture Environment Interactions, 10, 447-463. https://doi.org/10.3354/aei00282

Ruyet, J.P. (2002). Turbot (Scophthalmus maximus) Grow-out in Europe: Practices, Results, and Prospects. Turkish Journal of Fisheries and Aquatic Sciences, 2, 29-39.

Støttrup, J.G., Sparrevohna, C.R., Modinb, J. \& Lehmannc, K. (2002). The use of releases of reared fish to enhance natural populations: A case study on turbot Psetta maxima (Linne', 1758). Fisheries Research, 59, 161-180. https://doi.org/10.1016/S0165-7836(01)00413-1

Thorgaard, G.H., (1986). Ploidy Manipulation and Performance. Aquaculture, 57, 57-64. https://doi.org/10.1016/0044-8486(86)90180-8

Zengin, M., Polat, H., Kutlu, S., \& Gumus, A., (2007). An investigation on recruitment of hatchery-reared Black Sea turbot juveniles to natural stocks and its bioecological characteristics. Project Number: TAGEM/HAYSUD/2000/17/03/010, Final Report. Central Fisheries Research Institute, Trabzon, Turkey, $193 \mathrm{pp}$.

Zar, J.H., (1999) Biostatistical analysis. A Viacom Company, New Jersey, 870 pp. 